\title{
Spatial characterization of hygienic-sanitary indicators of refrigerated raw milk from three microregions of the Rondônia state
}

\section{Caracterização espacial dos indicadores higiênico-sanitários do leite cru refrigerado de três microrregiões do estado de Rondônia}

\author{
Juliana Alves Dias ${ }^{1 *}$; Ivanete Franceschini Pacheco ${ }^{2}$; Celia Regina Grego ${ }^{3}$; \\ Guilherme Vieira Faria ${ }^{4}$; Pedro Gomes da Cruz ${ }^{1}$
}

\begin{abstract}
Highlights:
Refrigerated milk SCC and SPC adequacy to the limits defined by legislation. Higher SCC and SPC in the rainy season for milk stored in refrigerated tanks. Highest SPC in collective tanks $>5$ producers in both rainy and dry seasons. Lower SPC in dry season for collective tanks $\leq 5$ producers.

Spatial dependence for SCC and SPC and indication of priority areas for action.
\end{abstract}

\begin{abstract}
Bacterial count (SPC) and somatic cell count (SCC) are considered universal indicators of milk quality. The objective of this study was to identify SPC and SCC clusters in milk samples from three microregions of the state of Rondônia and to evaluate the influence of year period and tank type on these indicators. A total of 566 milk cooling tanks linked to dairy industries with the Federal Inspection Service located in the Ariquemes, Ji-Paraná and Porto Velho microregions were evaluated. The SPC and SCC results of the tank samples and the geographical coordinates were obtained from the dairy industry database; the study focused on the results of official analyses carried out by the Laboratories of Milk Quality accredited to the Ministry of Agriculture, Livestock and Food Supply (MAPA) in 2015, constituting a pool of 6,792 data subsets from 2,209 farmers. To elaborate the spatial distribution maps of the quality indicators, the ArcView $3.1^{\circledR}$ software was used. Spatial dependence was evaluated by geostatistics, using the ordinary kriging method for data interpolation. Variance analysis (ANOVA) was performed using the SAS 9.0 GLM procedure on the logarithmic transformation of SCC and SPC, using as variables the type of tank (individual and collective) and season (dry and rainy). The frequency of milk quality adjustments to the limits defined in the legislation has shown that SPC is a major challenge for the state's production chain. There were no significant differences in this frequency for SCC and SPC, neither between the microregions studied, nor between the dry and rainy season $(p>0.05)$. The analysis of variance considered the period of year and type of cooling tank and showed higher SPC and SCC in the rainy season $(\mathrm{p}<0.05)$; SCC and SPC were higher in collective tanks used by more than 5 farmers $(p<0.05)$. Spatial dependence was weak for SCC $(D D=22.02)$ and moderate for SPC $(\mathrm{DD}=25.93)$, indicating the Machadinho do Oeste region as a priority area for mastitis control, and the Ariquemes microregion and west of the Porto Velho microregion as areas of high SPC. The results
\end{abstract}

1 Pesquisadores, Empresa Brasileira de Pesquisa Agropecuária, Embrapa Rondônia, Porto Velho, RO, Brasil. E-mail: juliana. dias@embrapa.br; pedro-gomes.cruz@embrapa.br

2 Bióloga, M.e em Ciências Ambientais, Universidade Federal de Rondônia, UNIR, Ji-Paraná, RO, Brasil. E-mail: ivanetefp@, hotmail.com

3 Pesquisadora, Empresa Brasileira de Pesquisa Agropecuária, Embrapa Informática Agropecuária, Campinas, SP, Brasil. E-mail: celia.grego@embrapa.br

4 Técnico, Empresa Brasileira de Pesquisa Agropecuária, Embrapa Rondônia, Porto Velho, RO, Brasil. E-mail: guilherme.faria@ embrapa.br

* Author for correspondence 
demonstrated the feasibility of spatial analysis as a tool for evaluating of refrigerated raw milk quality indicators and may support the definition of public and private strategies and policies to improve the milk quality and legislation adequacy.

Key words: Bacterial count. Kriging. Milk quality. Somatic cell count.

\section{Resumo}

A contagem bacteriana (CPP) e contagem de células somáticas (CCS) são considerados indicadores universais da qualidade do leite. O objetivo deste trabalho foi identificar clusters de CPP e CCS em amostras de leite cru resfriado de três microrregiões do estado de Rondônia e avaliar a influência do período do ano e tipo de tanque nestes indicadores. Foram avaliados 566 tanques de resfriamento de leite localizados nas microrregiões de Ariquemes, Ji-Paraná e Porto Velho, vinculados a indústrias lácteas com Serviço de Inspeção Federal (SIF). Os resultados de CPP e CCS das amostras de tanques e as coordenadas geográficas foram obtidas do banco de dados de indústrias lácteas e consideraram os resultados de análises oficiais realizadas em laboratórios credenciados ao Ministério da Agricultura, Pecuária e Abastecimento (MAPA), referentes ao período seco e chuvoso do ano de 2015. Para elaboração dos mapas de distribuição espacial dos indicadores de qualidade foi utilizado o programa ArcView $3.1^{\circledR}$. A dependência espacial foi avaliada por meio da geoestatística, utilizando o método de krigagem ordinária para interpolação dos dados. Para a análise de variância foi realizada a transformação logarítmica dos resultados de CCS e CPP. Para as variáveis, tipo de tanque (individual e coletivo) e período do ano (seco e chuvoso), foi utilizada análise de variância (ANOVA) pelo procedimento GLM do SAS 9.0. Foram avaliados 6.792 dados de análise e 2.209 produtores vinculados. A frequência de adequação dos indicadores de qualidade do leite aos limites definidos na legislação demonstrou que a CPP constitui um grande desafio para a cadeia produtiva do estado. Não foram observadas diferenças das frequências de adequação aos limites vigentes para CCS e CPP entre as microrregiões estudadas para o período seco e chuvoso $(\mathrm{p}>0,05)$. A análise de variância considerou o período do ano e tipo de tanque de resfriamento e demonstraram maiores CPP e CCS no período chuvoso $(\mathrm{p}<0,05)$. Considerando os tipos de tanque, a CCS e CPP foram mais elevadas nos tanques coletivos com mais de 5 produtores $(p<0,05)$. Houve dependência espacial fraca para CCS $(G D=22,02)$ e moderada para CPP $(\mathrm{GD}=25,93)$, indicando a região de Machadinho do Oeste como área prioritária para o controle da mastite, e a microrregião de Ariquemes e à oeste da microrregião de Porto Velho como áreas de alta CPP. Os resultados demonstraram a viabilidade da análise espacial como ferramenta para avaliar os indicadores de qualidade do leite cru e poderão subsidiar a definição de estratégias e de políticas públicas e privadas para melhoria da qualidade do leite e adequação à legislação.

Palavras-chave: Contagem bacteriana. Contagem de células somáticas. Krigagem. Qualidade do leite.

\section{Introduction}

Bacterial count and somatic cell count are universal indicators for raw milk quality and reflect the conditions of obtaining and storing milk and the health of the mammary gland, respectively. In Brazil, the rules for the milk production chain were defined in 2002 by the publication of Normative Instruction 51, and updated in 2011 and 2016. In 2018 Normative Instructions 76 and 77 revoked the previous normatives, thus starting a process of reorganization of the sector, aiming to meet the parameters defined for production, commercialization and modernization (Instrução Normativa $n^{\circ} 51,2002$; Instrução Normativa $n^{\circ} 76$, 2018; Instrução Normativa $n^{\circ} 77,2018$ ).

Milk production chain in Rondônia has been growing in recent years. The state is the seventh largest milk producer in Brazil that produced 1.16 billion liters in 2018 , representing $50.6 \%$ of the total production in the North region (Instituto Brasileiro de Geografia e Estatística [IBGE], 2019a). Milk production is family-based and involves 29,325 producers (Agência de Defesa Sanitária Agrosilvopastoril do Estado de Rondônia 
[IDARON], personal communication, September 3 , 2019). Dairy industries with federal inspection service (SIF) are responsible for processing $94.8 \%$ of industrialized milk (IBGE, 2019b) and, according to the data from the Federal Inspection Service's Management Information System (Sistema de Informação Gerenciais do Serviço de Inspeção Federal [SIGSIF], 2019), 37 SIF dairy industries are installed in the state, contributing to the sector modernization. Efforts by government, dairy companies and producers were especially directed towards improving raw milk quality. Structural advances, such as the acquisition of cooling tanks, improvement of road and electricity service are observed, however, studies demonstrate the predominance of low-technology milk producers, resulting in low productivity and high seasonality of production (Carvalho, 2012; Dias, Souza, Grego, \& Silva, 2013; Serviço de Apoio às Micro e Pequenas Empresas [SEBRAE], 2015).

Raw milk quality results, among other factors, from the milking conditions, the health of the herd and the storage of the raw material. Factors such as temperature and storage time of the milk are important as they are directly linked to the multiplication of microorganisms, thus affecting the bacterial count. According to the legislation, milk must be cooled to $4{ }^{\circ} \mathrm{C}$ within 3 hours after the end of milking, and the storage time of the milk in the cooling tank should not exceed 48 hours (Instrução Normativa $\left.n^{0} 77,2018\right)$. In Rondônia, dairy farming is characterized by the predominance of low production scale producers, so milk cooling in the state relies on collective tanks (SEBRAE, 2015). According to data collected by IDARON Agency in May 2019, in the state 6,548 cooling tanks are present and employed by 19,806 linked producers, $89 \%$ of which use collective tanks (IDARON, personal communication, September 3, 2019). A study carried out in the microregion of Ji-Paraná, RO on samples of raw milk stored in collective cooling tanks showed a median SPC of 965,000 CFU mL $\mathrm{mL}^{-1}$ and SCC of 242,000 cells $\mathrm{mL}^{-1}$, indicating the challenges of meeting the limit CPP defined in the legislation (Dias, Antes, Queiroz, \& Mendes, 2014).

Although studies have been carried out in the microregion of Ji-Paraná, the epidemiology of milk quality indicators in Rondônia is not clear, showing the importance of studies that characterize the frequency and pattern of distribution of these indicators in the microregions, as they may differ due to regional differences in production and management systems, sociocultural level, and animal genetics, among others. Clustering studies on milk quality already allowed the identification of regional differences that can assist in the management of herds in these regions (Ely, Smith, \& Oleggini, 2003; Gay, Barnouin, \& Senoussi, 2006).

Geographical attributes related to herds location and their health problems can be explored in geostatistical terms for analysis and identification of territories with similar spatial characteristics. Regional or country level decisions based on spatial epidemiological studies can significantly contribute to the development of territorial policies and assist in the definition of strategies for improving the health of their local dairy herds (Perry, McDermott, \& Randolph, 2001). Gay et al. (2006) demonstrated different patterns in herds SCC according to time (1996 to 2000) and regions of France, allowing the clustering of herds with low and high SCC. Studies carried out in the microregion of Ji-Paraná, Rondônia (Carvalho, 2012; Dias, Antes, Queiroz, Souza, \& Grego, 2015a), Espírito Santo (Souza et al., 2013) and Goiás (Neves, 2015) identified SCC and SPC clusters, demonstrating the feasibility of spatial analysis as a tool for evaluating milk quality indicators, which can be used for territorial decisionmaking to improve milk quality (Carvalho, 2012; Neves, 2015).

The definition of strategies for quality improvement based on regional epidemiological studies can be a tool for directing the actions of 
industries and producers, aiming at adapting the milk stored in cooling tanks to the parameters and limits defined in the legislation. Thus, the objective of this work was to identify clusters of CPP and CCS in samples of refrigerated raw milk from three microregions in the state of Rondônia and to evaluate the influence of the time of year and type of tank on the hygienic-sanitary quality indicators of milk.

\section{Material and Methods}

\section{Sampling Unit}

The study was carried out on 566 milk cooling tanks located in the microregions of Ariquemes $(\mathrm{n}=$ 186), Ji-Paraná $(\mathrm{n}=178)$, and Porto Velho $(\mathrm{n}=202)$ in the Rondônia state, linked to dairy industries with Service Federal Inspection Service (SIF) (Figure 1). Samplings were carried out during rainy and dry periods.

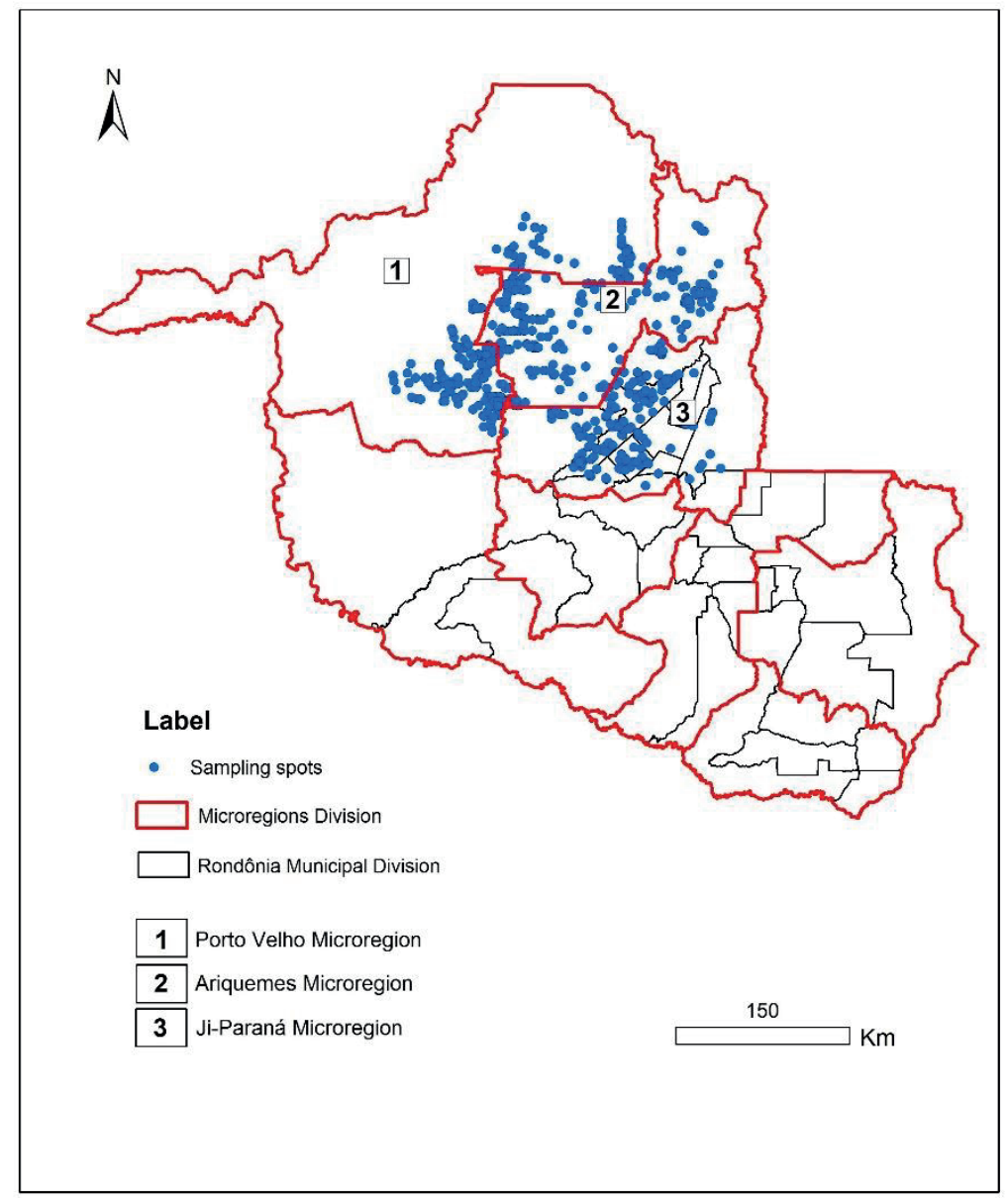

Figure 1. Geographical location of the cooling tanks sampled from the microregions of Ariquemes, Ji-Paraná, and Porto Velho, Rondônia, 2015 .

\section{Data and information}

The data were obtained from the dairy industry database regarding the results of official monthly analyses of cooling tank samples sent to laboratories accredited to the Ministry of Agriculture, Livestock and Food Supply (MAPA), to determine Standard Plate Count (SPC) and Somatic Cell Count (SCC). The SPC and SCC were determined using the flow cytometry method in automated equipment according to the International Organization for 
Standardization [ISO] (2006, 2013). The cooling tanks were selected only when three consecutive analyses were recorded in the rainy period (January, February and March) and dry period (June, July and August) of 2015.

Global Positioning System (GPS) equipment was used to obtain the geographical location of the tanks. Information was also obtained regarding the cooling tank, such as type of tank (individual or collective), and the number of producers who delivered milk to the collective tank.

\section{Data analysis}

Information regarding the results of the milk analysis and the variables, such as type of tank and number of producers per collective tank were stored in a database of the software Epiinfo 7.2.2.16. For calculating the geometric mean, the three consecutive measurements of the dry and the rainy periods were considered. The results of the analyses were assessed with a binary value considering the limits for the hygienic-sanitary indicators defined in Normative Instruction 76 (Instrução Normativa $\mathrm{n}^{\circ} 76,2018$ ): for $\mathrm{SPC}, \leq 300,000 \mathrm{CFU} \mathrm{mL} \mathrm{mL}^{-1}=0$; > $300,000 \mathrm{CFU} \mathrm{mL} \mathrm{m}^{-1}=1$; for $\mathrm{SCC}, \leq 500,000$ cells $\mathrm{mL}^{-1}=0 ;>500,000$ cells $\mathrm{mL}^{-1}=1$. The comparison of the frequency of adequacy of the results of the analyses was evaluated by the chi-square test $\left(\chi^{2}\right)$ using the software Epiinfo 7.2.2.16.

For the analysis of variance, logarithmic transformation of the SCC and SPC results was performed. For the variables, type of tank (individual and collective) and period of the year (dry and rainy), analysis of variance (ANOVA) was done using the GLM procedure of SAS 9.0. A t-test at $5 \%$ significance was used according to the model described:

$$
y_{i j}=\mu+\beta_{i}+\delta_{j}+\beta \delta_{i j}+e_{i j}
$$

Where:

$y$ is the response variable $\mu$ is the general average

$\beta$ is the type of tank in the $i$-th (individual, collective $\leq 5$ and collective $>5$ )

$\delta$ is the time of the $j$-th year (dry or rainy)

For spatial analysis, the geographic coordinates of the tanks, as well as the result of the geometric mean of the SCC and SPC, were included in the database and subsequently plotted on the georeferenced map of the state using the ArcView 3.1 ${ }^{\circledR}$ software. Spatial dependence was assessed using geostatistical analysis according to Vieira, Millete, Topp and Reynolds (2002). As spatial dependence was detected by adjusting the semivariogram, the values of the hygienic-sanitary indicators of the milk under study were estimated for the locations not sampled within the space, without bias and with minimal variance, using the ordinary kriging method for data interpolation.

Semivariograms were constructed assuming the stationary intrinsic hypothesis with the calculation of the semivariation $\gamma(\mathrm{h})$ according to the equation:

$$
\gamma(h)=\frac{1}{2 n} \sum_{i=1}^{n}\left[Z\left(x_{i}\right)-Z\left(x_{i}+h\right)\right]^{2}
$$

Where $\gamma(h)=$ semi-variance as a function of the distance $(h)$ of separation between pairs of points $Z(x) ; n=$ number of pairs of experimental points.

The spatially dependent semivariograms were adjusted with the spherical model according to the equation:

$$
\gamma(h)=C_{0}+C_{1}\left[\frac{3}{2}\left(\frac{h}{a}\right)^{3}-\frac{1}{2}\left(\frac{h}{a}\right)^{3}\right]
$$

Where $C_{0}=$ nugget effect (value of $\gamma(h)$ when $h=0$ ); $a=$ range (distance where $\gamma(h)$ remains approximately constant with increasing $h ; C_{0}+C_{l}=$ threshold (value of $\gamma(h)$ from $a$ ); and $C_{l}=$ structural variance (difference between the threshold and the nugget effect); $0<h<a$. 
Degree of dependence (DD) was calculated according to the equation:

$$
D D=\frac{C_{1}}{C_{0}+C_{1}} \cdot 100
$$

The DD result was categorized into: weak dependence $\leq 25 \%$, moderate dependency from $26 \%$ to $75 \%$, and strong dependence $>75 \%$.

\section{Results and Discussion}

The whole dataset consisted of 6,792 analysis from 2,209 linked producers. Of the 566 total tanks evaluated, 137 (24.2\%) were individual, 379 $(67.0 \%)$ collective, and $50(8.8 \%)$ did not have this information in the database. The average number of producers per collective tank was 5 , ranging from 2 to 81 .
Frequencies of the SCC and SPC indicators in the microregions by period of the year (dry and rainy) according to the limits defined in IN76 (Instrução Normativa $n^{\circ} 76,2018$ ) demonstrated that meeting the SPC limits is a major challenge for the state's production chain (Table 1). The frequency of cooling tanks with SPC results $>300,000 \mathrm{CFU} \mathrm{mL}^{-1}$ in the evaluated micro-regions varied from $59.7 \%$ to $66.8 \%$ in the rainy season, and from $53.2 \%$ to $55.4 \%$ in the dry season. There were no differences in the frequency of results considering the current limits for the hygienic-sanitary indicators between the micro-regions studied for the dry and rainy period $(p>0.05)$. However, there was a trend towards a higher frequency of tanks with SCC above 500,000 $\mathrm{mL}^{-1}$ cells in the Ariquemes microregion in the rainy season compared to the other two microregions studied $(\mathrm{p}=0.063)$.

\section{Table 1}

Hygienic-sanitary indicators in refrigerated raw milk from Ariquemes, Ji-Paraná, and Porto Velho microregions according to the limits defined by Normative Instruction 76 (IN76)

\begin{tabular}{|c|c|c|c|c|c|c|}
\hline \multirow[b]{2}{*}{ Hygienic-sanitary indicators } & \multirow[b]{2}{*}{ IN76 Limit } & \multicolumn{3}{|c|}{ Microregions } & \multirow{2}{*}{$\begin{array}{l}\text { Total } \\
\mathrm{n}(\%)\end{array}$} & \multirow[b]{2}{*}{ p-value } \\
\hline & & $\begin{array}{c}\text { Ariquemes } \\
\mathrm{n}(\%)\end{array}$ & $\begin{array}{c}\text { Ji-Paraná } \\
\text { n (\%) }\end{array}$ & $\begin{array}{c}\text { Porto Velho } \\
\mathrm{n}(\%)\end{array}$ & & \\
\hline \multicolumn{7}{|c|}{ Somatic Cell Count - SCC (cells $\left.m L^{-1}\right)$} \\
\hline \multirow{2}{*}{ Rainy period } & $\leq 500.000$ & $172(92.5)$ & $173(97.2)$ & $195(96.5)$ & $540(95.4)$ & \multirow{2}{*}{$0.063^{\mathrm{a}}$} \\
\hline & $>500.000$ & $14(7.5)$ & $5(2.8)$ & $7(3.5)$ & $26(4.6)$ & \\
\hline \multirow{2}{*}{ Dry period } & $\leq 500.000$ & $181(97.3)$ & $170(95.5)$ & $198(98.0)$ & $549(97.0)$ & \multirow{2}{*}{$0.342^{\mathrm{a}}$} \\
\hline & $>500.000$ & $5(2.7)$ & $8(4.5)$ & $4(2.0)$ & $17(3.0)$ & \\
\hline \multicolumn{7}{|c|}{ Standard Plate Count - SPC $\left(C F U \mathrm{~mL}^{-1}\right)$} \\
\hline \multirow{2}{*}{ Rainy period } & $\leq 300.000$ & $75(40.3)$ & $62(34.8)$ & $67(33.2)$ & $204(36.0)$ & \multirow{2}{*}{$0.314^{\mathrm{a}}$} \\
\hline & $>300.000$ & $111(59.7)$ & $116(65.2)$ & $135(66.8)$ & $362(64.0)$ & \\
\hline \multirow{2}{*}{ Dry period } & $\leq 300.000$ & $87(46.8)$ & $91(51.1)$ & $90(44.6)$ & $268(47.3)$ & \multirow{2}{*}{$0.433^{\mathrm{a}}$} \\
\hline & $>300.000$ & $99(53.2)$ & $87(48.9)$ & $112(55.4)$ & $298(52.7)$ & \\
\hline
\end{tabular}

a: $\mathrm{p}>0.05$ Chi-square test.

The result of the analysis of variance showed a significant difference for SCC $(p=0.0003)$ and $\mathrm{SPC}(\mathrm{p}<0.0001)$ between the dry and rainy periods (Tables 2 and 3), with higher counts of SPC and SCC in the rainy period. Studies carried out in the states of Rondônia (Carvalho, 2012) and Goiás (Neves et al., 2019) have shown higher SPC averages in the rainy period compared to the dry period. In Rondônia, the climate is classified as humid tropical (Type Am of the Köppen climate classification), and the rainy season is characterized by high rainfall, high temperatures and humidity (Alvares, 
Stape, Sentelhas, Gonçalves, \& Sparovek, 2014), which favors mud formation and multiplication of microorganisms. Mud formation at the animals' place of residence, associated with low adoption of good practices, increases the probability of microbiological contamination of the raw material during milking and the occurrence of intramammary infections (Silva et al., 2011; Matsubara et al., 2011; Oliveira, 2018). Studies carried out in the microregions of Ji-Paraná and Cacoal showed deficiencies in the physical infrastructure of the milking place of the animals and low adoption of good practices (Carvalho, 2012; Dias, Antes, Grego, \& Menezes, 2016a; Dias, Souza, Grego, \& Mendes, 2016b). Diverse factors, such as deficient transportation infrastructure and discontinuous electricity supply, may have contributed to higher CPP counts observed in the rainy season, a time when the situation worsens (SEBRAE, 2015).

Table 2

Somatic cell count in refrigerated raw milk, by type of cooling tank, rain and dry periods

\begin{tabular}{|c|c|c|c|}
\hline \multirow{2}{*}{ Somatic Cell Count (cells mL $\mathbf{L}^{-1}$ ) } & \multicolumn{2}{|c|}{ Period of the year } & \multirow{2}{*}{ Mean } \\
\hline & Rain & Dry & \\
\hline \multicolumn{4}{|l|}{ Type of tank } \\
\hline Individual tank & 265,578 & 240,854 & $253,216^{\mathrm{AB}}$ \\
\hline Collective tank $\leq 5$ producers & 252,282 & 231,974 & $242,128^{\mathrm{B}}$ \\
\hline Collective tank $>5$ producers & 272,253 & 233,174 & $252,714^{\mathrm{A}}$ \\
\hline Mean & $263,371^{\mathrm{a}}$ & $235,334^{\mathrm{b}}$ & \\
\hline Variation source & \multicolumn{3}{|c|}{ Probability } \\
\hline Period of the year & \multicolumn{3}{|c|}{0.0003} \\
\hline Type of tank & \multicolumn{3}{|c|}{0.0134} \\
\hline Interaction (Period of the year & \multicolumn{3}{|c|}{0.7806} \\
\hline
\end{tabular}

* Data transformed $\log 10(\mathrm{x})$

** Different uppercase letters in columns and lowercase letters in lines differ from each other in the T-test at 5\% of significance

$* * *$ Interactions with $\mathrm{p}<0.30$ had the degrees of freedom unfolded.

Table 3

Standard plate count in refrigerated raw milk, by type of cooling tank, rain and dry periods

\begin{tabular}{|c|c|c|c|}
\hline \multirow{2}{*}{ Standard Plate Count (CFU mL $\left.\mathbf{m L}^{-1}\right)$} & \multicolumn{2}{|c|}{ Period of the year } & \multirow{2}{*}{ Mean } \\
\hline & Rain & Dry & \\
\hline \multicolumn{4}{|l|}{ Type of tank } \\
\hline Individual tank & $789,262^{\mathrm{Ba}}$ & $666,099^{\mathrm{ABa}}$ & $727,680^{\mathrm{B}}$ \\
\hline Collective tank $\leq 5$ producers & $958,770^{\mathrm{ABa}}$ & $499,688^{\mathrm{Bb}}$ & $729,229^{\mathrm{B}}$ \\
\hline Collective tank $>5$ producers & $1,294,550^{\mathrm{Aa}}$ & $1,031,396^{\mathrm{Aa}}$ & $1,162,973^{\mathrm{A}}$ \\
\hline Mean & $1,014,194^{\mathrm{a}}$ & $732,394^{\mathrm{b}}$ & \\
\hline \multicolumn{2}{|l|}{ Variation source } & Probability & \\
\hline \multicolumn{2}{|l|}{ Period of the year } & $<0.0001$ & \\
\hline \multicolumn{2}{|c|}{ Type of tank } & 0.0001 & \\
\hline \multicolumn{2}{|c|}{ Interaction (Period of the year $x$ Type of tank) } & 0.2492 & \\
\hline
\end{tabular}


In the present study, the average $\mathrm{SCC}$ in the rainy and dry period was 263,371 cells $\mathrm{mL}^{-1}$ and 235,334 cells $\mathrm{mL}^{-1}$ respectively, below the limit defined in the current legislation $\left(500,000\right.$ cells $\left.\mathrm{mL}^{-1}\right)$ (Table 2 ). The low productivity of the animals and the low technification of the properties observed in the state impacted the SCC results of the milk stored in the evaluated tanks. Dias, Antes and Queiroz (2015b) demonstrated that variables related to the properties' technification and SCC $>400,000 \mathrm{~mL}^{-1}$ cells were associated with the presence of Staphylococcus aureus, the main microorganism that causes bovine mastitis.

In the state of Rondônia, milk is cooled and stored predominantly in collective tanks (SEBRAE, 2015; IDARON, personal communication, September 3, 2019). In the present study, the categorization of tanks considered the average number of producers per tank, and the results showed that SPC was significantly higher in collective tanks with more than 5 producers $(\mathrm{CT}>5)$ compared to collective tanks with less than or equal number to 5 producers $(\mathrm{CT} \leq 5)$ and individual tanks (Table 3). Studies carried out in the microregion of Ji-Paraná, Rondônia (Carvalho, 2012; Dias et al., 2014) and Minas Gerais (Cunha et al., 2016), showed higher SPC in collective tanks compared to individual ones. According to Brito, Souza, Lange and Brito (2009), the high bacterial count observed in milk stored in collective tanks can be related to the individual deficiencies of producers in milking hygiene, which compromises the microbiological quality of the production. Failures in the cooling logistics of milk in collective tanks, associated with favorable climatic conditions contribute to the multiplication of microorganisms and to high counts of bacteria in the milk.

In the study by Dias et al. (2015a), the presence of intermediaries in the collective tank was considered a risk factor, increasing the probability

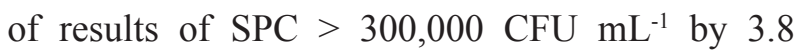
times when compared to the herds in which milk was delivered directly to the tank by producers. In collective tanks with the presence of intermediaries, many negatively influencing factors were observed: a greater distance between the property and the tank, a longer period of time between milking and cooling the milk, deficient washing of the cans, and permanence of the cans in the benches without cover (Dias et al., 2016b). The presence of intermediaries or carters also establishes another stage in transportation, which may be subject to delays, thus further increasing both the time needed for the delivery of the milk in the tank and the microbial multiplication in the milk, especially in the hottest months of the year (Brito et al., 2003). In the present study, CT $>5$ showed higher SPC in the two periods evaluated (Table 3), demonstrating that this strategy should be reevaluated, considering the risk factors involved.

Milk samples from $\mathrm{CT} \leq 5$ producers showed an average SPC of 729,229 CFU mL $\mathrm{mL}^{-1}$, showing a significant difference in bacterial count between the periods evaluated, with higher SPC in the rainy season (Table 3). In collective tanks with a smaller number of producers, milk delivery to the tank is often carried out by the producer, due to shorter distances between the property and the tank. In the present study, the lower SPC demonstrated in the dry period for this type of tank may be related to a lesser exposure to environmental factors (mud) and structural challenges (roads and bridges) for the delivery of milk in the tank compared to the rainy season.

The SPC result observed in the individual cooling tanks showed an average of 727,680 CFU $\mathrm{mL}^{-1}$, with no difference in count between the periods evaluated (Table 3). In Rondônia, cooling tanks are made available to producers by the private sector (dairy industries), and individual tanks are installed on farms with higher milk production, with a higher number of lactating animals being observed in this property profile and a higher frequency adoption of mechanical milking. The use of mechanical milking and the presence of more than 16 lactating cows on the farm were considered risk factors associated 
with $\mathrm{SPC}>300,000 \mathrm{CFU} \mathrm{mL} \mathrm{mL}^{-1}$ and $\mathrm{SPC}>100,000$ UFC $\mathrm{mL}^{-1}$ respectively, in milk samples from herds in Rondônia (Dias et al., 2015a). The risks related to the profile of properties with individual tanks, are partly related to the low adoption of good milking practices and failures in the washing and maintenance processes of milking equipment. Bava et al. (2011) demonstrated that the milking machine washing procedures, classified by water temperature and detergent concentration, contribute significantly to discriminate properties with low and high SPC in the tank. In a study carried out in Goiás, higher SPC was observed in mechanical milking systems compared to manual milking (Brasil et al., 2012).

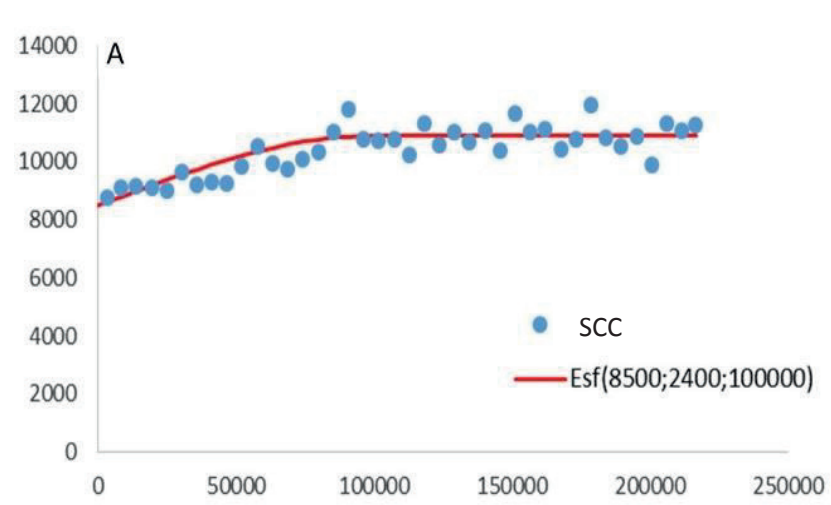

\section{Spatial analysis}

The results of the spatial analysis demonstrated weak spatial dependence for somatic cell count $(\mathrm{SCC})\left(\mathrm{DD}=22.02 ; \mathrm{r}^{2}=0.73\right)$ in the studied tanks, at up to $100 \mathrm{~km}$ (Figure 2), indicating low accuracy in the identification of areas with common characteristics. Carvalho (2012) observed moderate spatial dependence for SCC in herds in the microregion of Ji-Paraná, Rondônia, demonstrating greater precision in the definition of common areas compared to the present study.

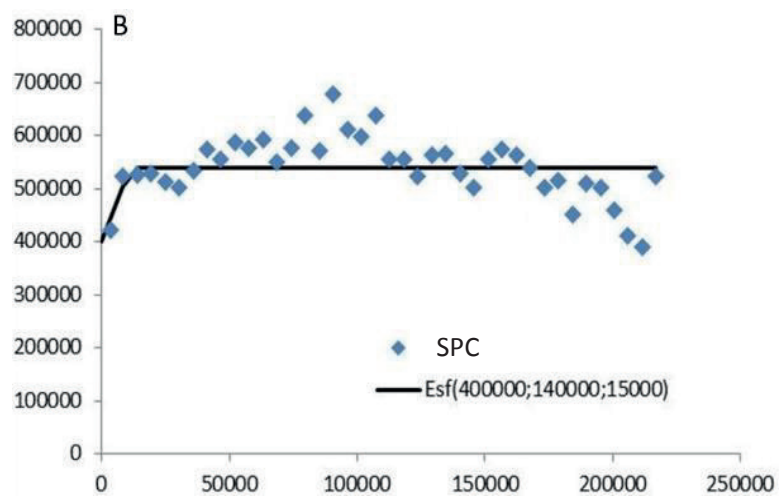

Figure 2. Semivariograms with spherical adjustment parameters (Esf $(\mathrm{C} 0 ; \mathrm{C} 1 ; \mathrm{a}))$ for Somatic Cell Count - SCC (A) and Standard Plate Count - SPC (B).

The spatial distribution of SCC is shown in Figure 3, and demonstrated counts below the limit of $500,000 \mathrm{~mL}^{-1}$ cells in most of the studied microregions. Higher SCC were observed in regions of the municipality of Machadinho do Oeste, microregion of Ariquemes. Although the geometric mean of the results met the limit of the current legislation, the distribution of areas with counts below $200,000 \mathrm{~mL}^{-1}$ cells is low, a limit defined to estimate the occurrence of subclinical mastitis (Dohoo \& Leslie, 1991; Ruegg \& Pantoja, 2013).
Variables related to technification were considered at risk for the occurrence of subclinical mastitis in Rondônia (Dias et al., 2013). In the municipality of Machadinho do Oeste, public and private initiatives have been carried out with a focus on pasture management and genetic improvement of dairy herds, which may have contributed to the increase in animal productivity and milk production in the region observed in recent years (Osmari, Cararo, Cipriani, Dias, \& Paz, 2015; IDARON, personal communication, September 3, 2019). 


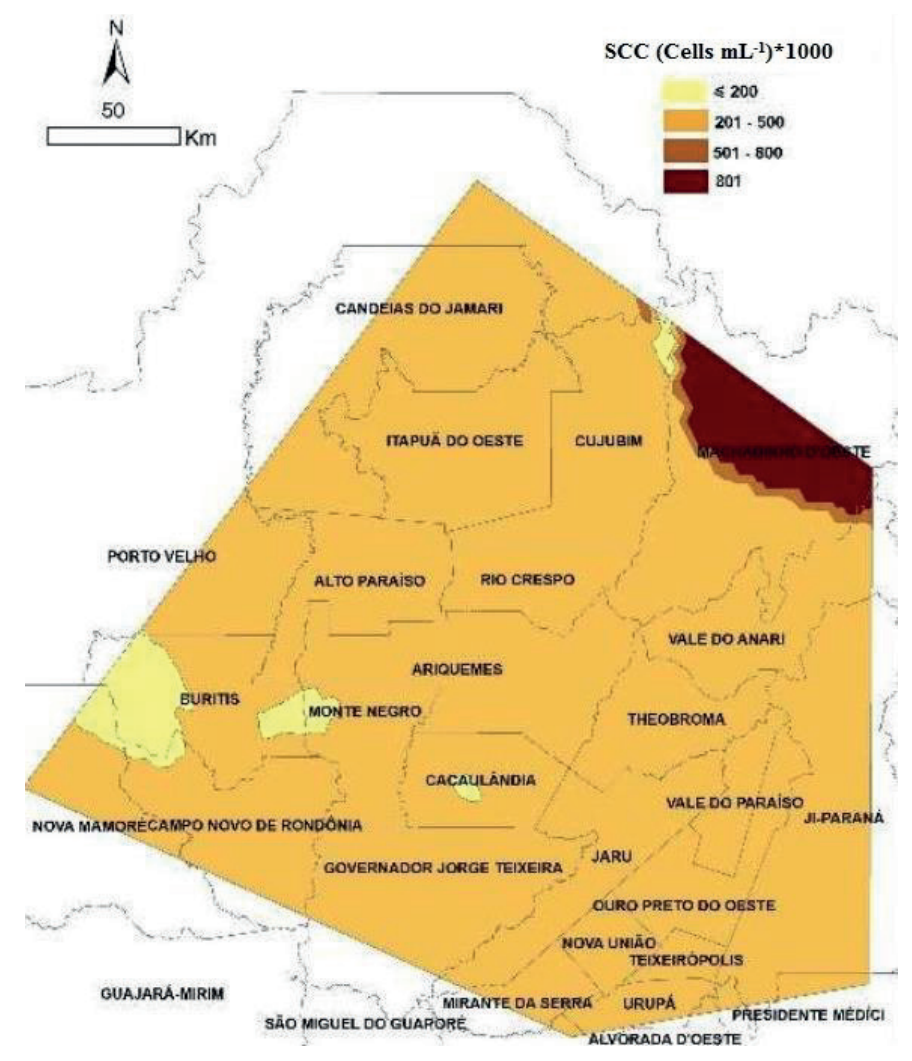

Figure 3. Spatial distribution of somatic cells count (SCC) values of refrigerated raw milk from Ariquemes, Ji-Paraná, and Porto Velho microregions.

The results of the spatial analysis demonstrated moderate spatial dependence for the bacterial count $(\mathrm{SPC})\left(\mathrm{DD}=25.93 ; \mathrm{r}^{2}=0.17\right)$, for a distance up to $15 \mathrm{~km}$ between the evaluated tanks (Figure 2), indicating greater precision in identifying areas with common characteristics. These results can be used for decision-making at the regional level to define strategies to reduce SPC. The results of the spatial distribution of SPC (Figure 4) demonstrated high counts in the three microregions, with few areas presenting counts below $300,000 \mathrm{CFU} \mathrm{mL}^{-1}$, and areas with counts above $1,000,000 \mathrm{CFU} \mathrm{mL}^{-1}$ in the central and southwest regions, indicating the microregion of Ariquemes and the west of the microregion Porto Velho as priority areas of activity for institutions linked to the sector. Studies carried out in the micro-regions of Ji-Paraná and Cacoal have shown that the presence of an intermediate (carriage) in the delivery of milk in the collective tank was associated with clusters of high bacterial counts in raw milk (Dias et al., 2015a; Dias et al., 2016b). 


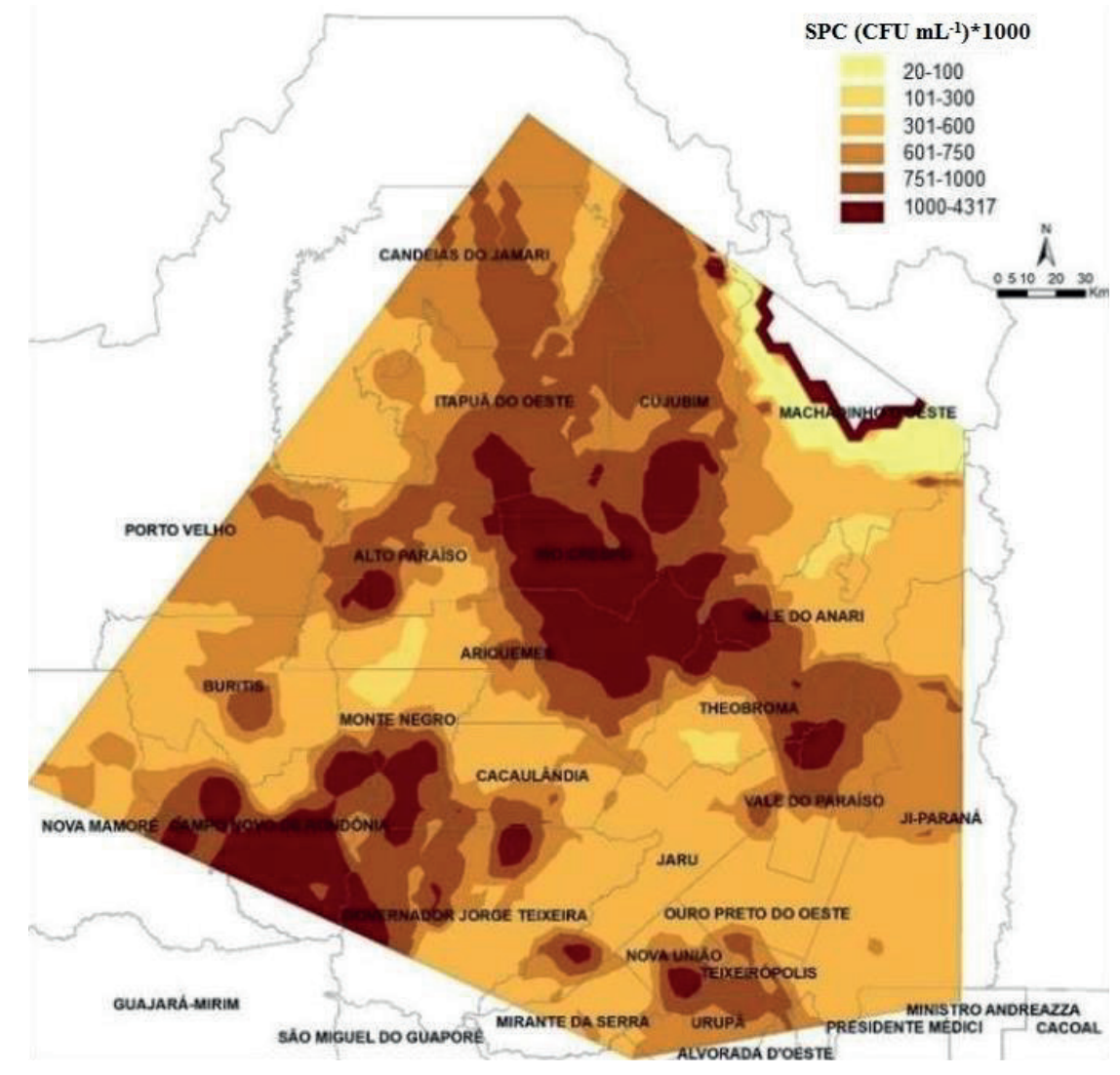

Figure 4. Spatial distribution of standard plate count (SPC) values of refrigerated raw milk from Ariquemes, Ji-Paraná, and Porto Velho microregions.

\section{Conclusions}

The microregions studied showed a high frequency of adequacy to the results in samples of refrigerated raw milk to the SCC limit defined by law, however geometric averages show results above $200,000 \mathrm{~mL}^{-1}$ cells, indicating that it is important to adopt measures for prevention and control of mastitis in herds located in the micro-regions studied, especially the region of the municipality of Machadinho do Oeste.

Thehigh frequency of SPC results in disagreement with the standard demonstrates the great challenge for producers and industries regarding the adequacy to the SPC limit defined in the legislation. Due to high SPC, the use of TC $>5$ should be reassessed as a strategy for cooling and preserving the milk obtained from small producers, in order to reduce and/or eliminate the risk factors associated with bacterial count of the raw material. Strategies for improving the microbiological quality of milk must be defined for all regions evaluated, giving priority to regions with high CPP, represented by the microregion of Ariquemes and the west of the microregion Porto Velho.

\section{Acknowledgments}

The authors would like to thank the dairy industries for provided data and information, the Rondônia Foundation for the Support of the Development of Scientific and Technological Actions and the Research of the State of Rondônia (FAPERO), the State Secretary of Agriculture of the State of Rondônia (SEAGRI) and the Coordination for the Improvement of Higher Education Personnel (CAPES). 


\section{References}

Alvares, C. A., Stape, J. L., Sentelhas, P. C., Gonçalves, J. L. M., \& Sparovek, G. (2014). Köppen's climate classification map for Brazil. Meteorologische Zeitschrift, 22(6), 711-728. doi: 10.1127/0941-2948/ 2013/0507

Bava, L., Zucali, M., Sandrucci, A., Brasca, M., Vanoni, L., Zanini, L., \& Tamburini, A. (2011). Effect of cleaning procedure and hygiene condition of milking equipment on bacterial count of bulk tank milk. Journal of Dairy Research, 78(2), 211-219. doi: 10.1017/S002202991100001X

Brasil, R. B., Silva, M. A, P., Carvalho, T. S., Cabral, J. F., Nicolau, E. S., \& Neves, R. B. S. (2012). Avaliação da qualidade do leite cru em função do tipo de ordenha e das condições de transporte e armazenamento. Revista Instituto Cândido Tostes, 389(67), 34-42. doi: 10.5935/2238-6416.20120076

Brito, M. A. V. P., Portugal, J. A. B., Diniz, F. H., Fonseca, P. C., Ângelo, F. F., \& Porto, M. A. C. (2003). Qualidade do leite armazenado em tanques de refrigeração comunitários. In C. E. Martins, P. C. Fonseca, W. F. Bernardo, A. C. Cóser, P. R. V. Franco, J. A. B. Portugal, \& F. S. de Carvalho (Eds.), Alternativas tecnológicas, processuais e de políticas públicas para a produção de leite em bases sustentáveis (pp. 21-34). Juiz de Fora: EMBRAPA Gado de Leite.

Brito, P. V. A. M., Souza, G. N., Lange, C. C., \& Brito, F. R. J. (2009). Qualidade do leite armazenado em tanques coletivos. (Circular Técnica, 99). Juiz de Fora, MG: EMBRAPA Gado de Leite.

Carvalho, G. L. O. (2012). Uso da análise espacial para avaliação de indicadores de qualidade do leite na microrregião de Ji-Paraná, Rondônia, 2011. Dissertação de mestrado, Universidade Federal de Juiz de Fora, Juiz de Fora, MG, Brasil.

Cunha, F. A. da, Costa, F. Z. H., Santos, M. F. T., Silva, Q. S., Souza, N. F. de, \& Cerqueira, P. O. M. M. (2016). Evolução anual da qualidade do leite cru de tanques individuais e comunitários do Vale do Rio Doce (MG). Boletim do Centro de Pesquisa de Processamento de Alimentos, 34(1), (p. 27-36). doi: 10. 5380/cep.v34i1.48970

Dias, J. A., Antes, F. G., \& Queiroz, R. B. (2015b). Prevalência e fatores de risco associados à ocorrência de Staphylococcus aureus em amostras de leite total de rebanhos da microrregião de Ji-Paraná, Rondônia. Anais do Congresso Brasileiro de Qualidade do Leite, Curitiba, PR, Brasil, 6.
Dias, J. A., Antes, F. G., Grego, C. R., \& Menezes, C. A. (2016a). Distribuição espacial e fatores de risco associados à ocorrência de resíduos de antimicrobianos em rebanhos leiteiros da microrregião de Ji-Paraná, Estado de Rondônia. (Documentos, 163). Porto Velho, RO: EMBRAPA Rondônia.

Dias, J. A., Antes, F. G., Queiroz, R. B., \& Mendes, M. M. (2014). Qualidade do leite armazenado em tanques de resfriamento de Rondônia. (Comunicado Técnico, 393). Porto Velho, RO: EMBRAPA Rondônia.

Dias, J. A., Antes, F. G., Queiroz, R. B., Souza, G. N., \& Grego, C. R. (2015a). Distribuição espacial e fatores de risco associados à contagem total bacteriana em amostras de leite total de rebanhos do estado de Rondônia. Anais do Congresso Brasileiro de Qualidade do Leite, Curitiba, PR, Brasil, 6.

Dias, J. A., Souza, G. N., Grego, C. R., \& Silva, M. R. (2013). Avanços e desafios enfrentados para obtenção de leite com qualidade na região norte. In E. N. Fernandes, A. S. Guimarães, C. E. Martins, C. R. Townsend, F. C. Ferreira, F. C. F. Lopes, J. A. B. Portugal, J. A. Dias, L. G. Brito \& M. Magalhães (Eds.), Alternativas para a produção sustentável de leite na Amazônia, (pp. 75-96). Brasília, DF: EMBRAPA.

Dias, J. A., Souza, M. G., Grego, C., \& Mendes, M. A. (2016b). Impacto da iniciativa de pagamento por qualidade do leite sobre indicadores higiênicossanitários de tanques de resfriamento de leite. (Boletim de Pesquisa e Desenvolvimento, 78). Porto Velho, RO: EMBRAPA Rondônia.

Dohoo, I. R., \& Leslie, K. E. (1991). Evaluation of changes in somatic cell counts as indicators of new intramammary infections. Preventive Veterinary Medicine, 10(3), 225-237. doi: 10.1016/01679877(91) 90006-N

Ely, L. O., Smith, J. W., \& Oleggini, G. H. (2003). Regional production differences. Journal Dairy Science, 86(Esp. Suppl.), 28-34. doi: 10.3168/jds. S0022-0302(03)74037-5

Gay, E., Barnouin, J., \& Senoussi, R. (2006). Spatial and temporal patterns of herd somatic cell score in France. Journal Dairy Science, 89(7), 2487-2498. doi: 10.3168/jds.500-0302(06)72323-2

Instituto Brasileiro de Geografia e Estatística (2019a). Pesquisa da Pecuária Municipal - PPM. Recuperado de https:/www.ibge.gov.br/estatisticas/economicas/ agricultura-e-pecuaria/9107-producao-da-pecuariamunicipal.html 
Instituto Brasileiro de Geografia e Estatística (2019b). Pesquisa Trimestral do Leite. Recuperado de https://www.ibge.gov.br/estatisticas/economicas/ agricultura-e-pecuaria/9209-pesquisa-trimestral-doleite.html

Instrução Normativa $n^{\circ} 51$ de 18 de setembro de 2002. Regulamento Técnico de Produção, Identidade e Qualidade do Leite Tipo A, Tipo B, Tipo C e Cru Refrigerado. Diário Oficial da União, Brasília, 20 de setembro de 2002. Seção 1, p. 13. Ministério da Agricultura, Pecuária e Abastecimento.

Instrução Normativa $n^{\circ} 76$, de 26 de novembro de 2018. Dispõe sobre regulamentos técnicos que fixam a identidade e as características de qualidade que devem apresentar o leite cru refrigerado, o leite pasteurizado e o leite pasteurizado tipo A. Diário Oficial da União, Brasília, 30 de novembro de 2018. Seção 1, p. 09. Ministério da Agricultura, Pecuária e Abastecimento.

Instrução Normativa $n^{o} 77$, de 26 de novembro de 2018. Dispõe sobre os critérios e procedimentos para a produção, acondicionamento, conservação, transporte, seleção e recepção do leite cru em estabelecimentos registrados no serviço de inspeção oficial. Diário Oficial Diário Oficial da União, Brasília, 30 de novembro de 2018. Seção 1, p. 10. Ministério da Agricultura, Pecuária e Abastecimento.

International Organization for Standardization (2006). Milk - Enumeration of somatic cells- Part 2: Guidance on the operation of fluoro-opto-electronic counters (ISO 13366-2|IDF 148-2:2006). Retrieved from https://www.iso.org/standard/40260.html

International Organization for Standardization (2013). Milk - Bacterial count - Protocol for the evaluation of alternative methods (ISO 16297 | IDF 161:2013). Retrieved from https://www.iso.org/standard/56110. html

Matsubara, M. T., Beloti, V., Tamanini, R., Fagnani, R., Silva, L. C. C., Monteiro, A. A.,... Barros, M. A. F. (2011). Boas práticas de ordenha para redução da contaminação microbiológica do leite no agreste Pernambucano. Semina: Ciências Agrárias, 32(1), 277-286.

Neves, R. B. S. (2015). Distribuição temporal e espacial da qualidade do leite no estado de Goiás. Tese de doutorado, Universidade Federal de Goiás, Goiânia, GO, Brasil.

Neves, R. B. S., Mesquita, A. J. de, Santos, M. V., Nicolau, E. S., Bueno, C. P., \& Coelho, K. O. (2019). Avaliação sazonal e temporal da qualidade do leite cru goiano tendo como parâmetros a contagem celular somática e a contagem bacteriana total. Archives of Veterinary Science, 24(1), 10-23. doi: 10. 5380/avs.v24i1.59996

Oliveira, A. M. (2018). Qualidade microbiológica do leite cru em tanques de resfriamento coletivos $e$ em sistemas de produção de leite prevalentes em Rondônia. Dissertação de mestrado, Universidade Federal de Rondônia, Porto Velho, RO, Brasil.

Osmari, E. K., Cararo, D. C., Cipriani, H. N., Dias, J. A., \& Paz, E. F. (2015). Adoção de tecnologias do projeto Arco Verde em propriedades leiteiras na Amazônia Legal. Anais do Congresso Internacional do Leite: Workshop de Políticas Públicas: Simpósio de Sustentabilidade da Atividade Leiteira, Juiz de Fora, MG, Brasil, 13, 13, 14.

Perry, B., McDermott, J., \& Randolph, T. (2001). Can epidemiology and economics make a meaningful contribution to national animal-disease control? Preventive Veterinary Medicine, 48(4), 231-260. doi: 10.1016/50167-5877(00)00203-8

Ruegg, P. L., \& Pantoja, J. C. F. (2013). Understanding and using somatic cell counts to improve milk quality. Irish Journal of Agricultural and Food Research, 52(2), 101-117.

Serviço de Apoio às Micro e Pequenas Empresas (2015). Diagnóstico do Agronegócio do leite e seus derivados no estado de Rondônia. Porto Velho, RO: SEBRAE.

Silva, L. C. C., Beloti V., D’Ovidio, L., Mattos, M. R., Arruda, A. M. C. T., \& Pires, E. M. F. (2011). Rastreamento de fontes de contaminação microbiológica do leite cru durante a ordenha em propriedades leiteiras do Agreste Pernambucano. Semina: Ciências Agrárias, 32(1), 267-276.

Sistema de Informação Gerenciais do Serviço de Inspeção Federal (2019). Relatório de estabelecimentos. Ministério da Agricultura Pecuária e Abastecimento. Retrieved from http://sigsif.agricultura.gov.br/ sigsif/principal_sigsif

Souza, G. N., Grego, C. R., Hott, M. C., Silva, M. R., Bruno, A. F., Hylario, S. M., \& Ziech, R. E. (2013). Avaliação espacial dos indicadores de qualidade do leite no estado do Espírito Santo, 2011-2012. Revista $M V \& Z, 11(1), 68$.

Vieira, S. R., Millete, J., Topp, G. C., \& Reynolds, W. D. (2002). Handbook for geostatistical analysis of variability in soil and climate data. In V. H. Alvarezz, C. R. Schaefer, N. F. Barros, J. W. V. Mello \& L. M. Costa (Eds.), Tópicos em ciência do solo (v. 2, pp. 1-45). Viçosa, MG: Sociedade Brasileira de Ciência do Solo. 
